\title{
Plant infesting arthropods sold in supermarkets in the Federal District, Brazil
}

\author{
Marcelo Tavares de Castro ${ }^{\mathrm{a} *}{ }^{*}$, Sandro Coelho Linhares Montalvão ${ }^{\mathrm{b}}$ \\ ${ }^{a}$ Centro Universitário ICESP de Brasília, Brasil \\ ${ }^{\mathrm{b}}$ Embrapa Recursos Genéticos e Biotecnologia, Brasil \\ *Autor correspondente (marceloengflorestal@gmail.com)
}

\section{N F O}

Keywords
entomology
phytosanitarity
phytophagous insects
red spider mite

Palavras-chaves entomologia fitossanidade insetos fitófagos ácaro-rajado

\begin{abstract}
A B S T R A C T
Many Brazilian supermarkets offer ornamental and fruit plants for sale, and many become infested by insects and other arthropods during commercialization. This work reflects the importance of knowing the pests that occur in these plants, to verify possible dissemination of these arthropods to other areas. This study was carried out with monthly visits to five supermarkets chosen at random in the Federal District, Brazil. The plants were identified and visually inspected for the presence of insects and other arthropods. The collected specimens were preserved in jars containing $70 \%$ alcohol. Their respective levels of infestation and damage were also observed and noted. Each specimen collected was identified according to specific books and keys for each taxonomic group collected. As a result, 65 plants were found to be infested with insects and mites. Of these, 48 contained sucking insects (Hemiptera) and 17 had spider mites (Tetranychus urticae Koch). Although the insects found are relatively common and have already been reported to be associated with several ornamental plants, this is the first work that records the occurrence of arthropods in ornamentals sold in commercial establishments.
\end{abstract}

\section{R E S U M O}

Artrópodes infestantes de plantas comercializadas em supermercados no Distrito Federal, Brasil

Os principais mercados brasileiros oferecem plantas ornamentais e frutíferas para a venda e muitas delas acabam sendo infestadas por insetos e outros artrópodes durante a comercialização. Esse trabalho reflete a importância de se conhecer as pragas que ocorrem nessas plantas, com o propósito de verificar um possível meio de disseminação desses animais para outras áreas. O presente trabalho foi realizado com visitas mensais em cinco supermercados escolhidos de forma aleatória situados no Distrito Federal, Brasil. As plantas foram identificadas e inspecionadas visualmente quanto à presença de insetos e outros artrópodes. Os espécimes coletados foram preservados em potes contendo álcool $70 \%$ e seus respectivos níveis de infestação e danos também foram observados e anotados. A identificação de cada exemplar coletado foi feita de acordo com livros e chaves específicas para cada grupo taxonômico encontrado. Como resultado, foram encontradas 65 plantas infestadas com insetos e ácaros. Destas, 48 continham insetos sugadores (Hemiptera) e 17 estavam com ácaro-rajado (Tetranychus urticae Koch). Apesar dos insetos encontrados serem relativamente comuns e já terem sido relatados associados a várias plantas ornamentais, esse é o primeiro trabalho que registra a ocorrência de artrópodes em ornamentais vendidas em estabelecimentos comerciais. 


\section{INTRODUCTION}

The main supermarket chains located in the Federal District and in Brazilian states sell flowers, ornamental plants, and some fruit and aromatic species (Silva, 2016). The ornamental plant and flower trade are divided into three main distribution channels to the consumer (Nevez and Pinto, 2015), in which supermarkets represent an important selfservice channel for these products (Rosa and Lunkes, 2006).

Potted flowers represent $50 \%$ of the market in the Federal District, followed by cut flowers (40\%), and finally green plants $(10 \%)$, such as palm trees, aromatics, tree seedlings, and shrubs (GDF, 2007). Study about the presence and infestation of insects and other arthropods in plants sold at these establishments is practically non-existent.

Insects and other animals are considered pests in agriculture when they cause economic damage in commercial plantations, within the scope of integrated management (Gallo et al., 2002; Imenes e Ide, 2002; Costa et al., 2008). When they are not effectively controlled, pests can cause huge losses and easily spread to other regions. Correct identification and marking of the occurrence of these organisms are essential for efficient integrated pest management (Picanço, 2010; Fujihara et al., 2016).

Dynamics of arthropods populations dispersal are important to formulate integrate pest management programs. Insects and mites can be dispersed or disseminated into a new area by wind, water, man and contamined materials, like mechanical implements, plants, and packages, for example (Fraga et al., 2009). Commercial establishments can disseminate insects and mites pests by contamminated plants and seedlings to exotic areas (Ducroquet, 1996; Hickel et al., 1997). Very few studies have looked at insects carried by plants sold in commercial establishments, such as supermarkets.

Knowledge about the species that occur in the observed locations is needed to record those organisms that can cause economic damage. In the future, efficient measures could be proposed to avoid the dissemination and dispersion of organisms potentially harmful to plants. Therefore, this work aimed to survey potentially harmful arthropods associated with plants sold in supermarkets in the Federal District, Brazil.

\section{MATERIAL AND METHODS}

The study was carried out with monthly visits to five supermarkets chosen at random located in the
Federal District, Brazil, for one year (July 2018 to June 2019). All the supermarkets are cadastrated at "Registro Nacional de Sementes e Mudas" RENASEM/MAPA, Brazil, for seedlings comercialization. The plants sold in the gardening, floriculture, and fruit growing sessions were analyzed.

At each visit, the plants of this sessions were visually inspected for the presence of insects and other arthropods, such as mites. Those that showed infestations or signs of attack were collected, placed in plastic bags, and taken for analysis to the Laboratório de Ciências Vegetais from the University Center (ICESP) in Brasília, Águas Claras campus, Federal District, Brazil. The count of infested and non infested plants number was made when at least one plant with arthropod was observed.

The collected arthropod specimens were preserved in jars containing 70\% alcohol until their identification. The identification of each specimen collected was made according to specific books and keys for each taxonomic group found, mainly using the work of Fujihara et al. (2016). The pest arthropods most commonly known to science were identified at the species level and their damage were observed and evaluated.

\section{RESULTS AND DISCUSSION}

Sixty-five plants of 183 (35.51\%), from 10 different families, genus and species were found infested with insects and mites (Figure 1, Table 1). Of these, 48 (73.84\%) contained sucking insects (Hemiptera) and $17(26.16 \%)$ were infested with the spider mite (Tetranychus urticae (Koch), Tetranychidae). The infested plant species were arruda (Ruta graveolens L., Rutaceae); rose (Rosa sp., Rosaceae); azalea (Rhododendron sp., Ericaceae); desert rose (Adenium obesum (Forssk.) Roem. e Schult, Apocynaceae); ixora (Ixora sp., Rubiaceae); elephant's foot (Beaucarnea recurvata Lem., Asparagaceae); centipede tongavine (Epipremnum pinnatum (L.) Engl., Araceae); asparagus fern (Asparagus densiflorus, Asparagaceae); willow-leaved justicia (Justicia gendarussa Burm f., Acanthaceae); and pepper (Capsicum sp., Solanaceae).

Campos-Farinha (2006) reports that sucking insects are among the main arthropods that damage ornamental plants and can, on many occasions, be easily found associated with these plants. In addition to these insects, the spider mite is an important pest in ornamentals and potted flowers (Tamai et al., 2000, Feres et al., 2009; Santos et al., 2010; Sulzbach et al., 2015). 

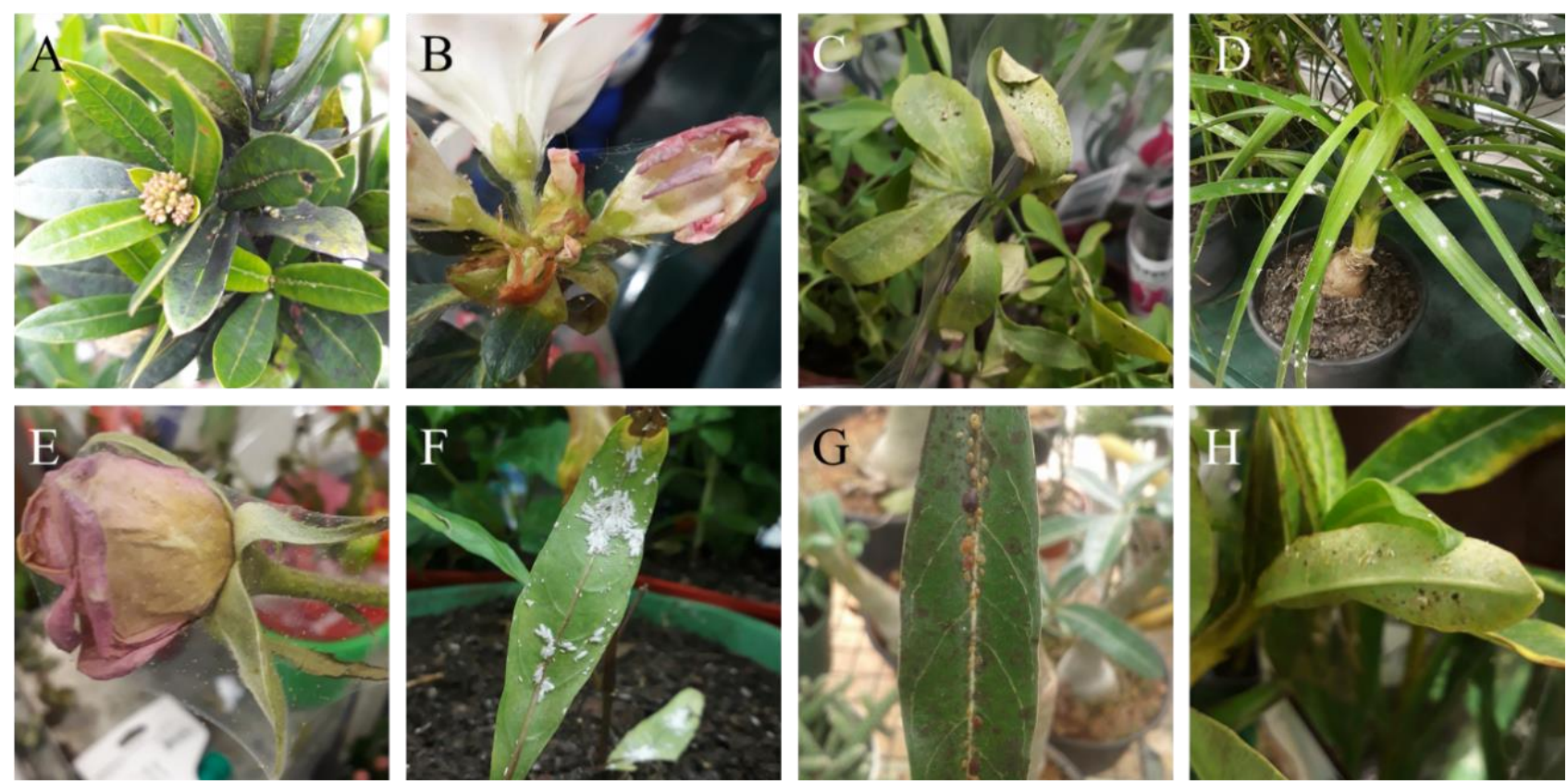

Figure 1 - Plants sold in supermarkets and infested with insects and mites in the Federal District, Brazil. A Ixora with mealybugs of the Coccidae family. B and C - Azalea and arruda with spider mite, respectively. D - Elephant's foot with scale insects of the family Pseudococcidae. E - Rose with spider mite. F - Willowleaved justicia with mealybugs in the family Pseudococcidae. G - Desert rose with mealybugs of the Coccidae family. $\mathrm{H}-$ Desert rose with whitefly.

Table 1 - Arthropods found in plants sold in supermarkets in the Federal District, Brazil.

\begin{tabular}{llllcc}
\hline \multicolumn{1}{c}{ Host } & \multicolumn{1}{c}{ Name } & \multicolumn{1}{c}{ Order } & \multicolumn{1}{c}{ Famíly } & $\begin{array}{c}\text { N }{ }^{\circ} \text { infested } \\
\text { plants }\end{array}$ & Total \\
\hline Arruda & Spider mite & Trobidiformes & Tetranychidae & 7 & 12 \\
Asparagus fern & Scale insect & Hemiptera & Pseudococcidae & 2 & 7 \\
Azalea & Spider mite & Trobidiformes & Tetranychidae & 4 & 16 \\
Centipede tonga- & Scale insect & Hemiptera & Pseudococcidae & 3 & 16 \\
vine & White fly & Hemiptera & Aleyrodidae & 15 & 33 \\
Desert Rose & Scale insect & Hemiptera & Coccidae & 4 & 13 \\
& Scale insect & Hemiptera & Pseudococcidae & 6 & 11 \\
Ixors & Scale insect & Hemiptera & Coccidae & 8 & 35 \\
Justicia & Scale insect & Hemiptera & Pseudococcidae & 2 & 8 \\
Peper & Aphid & Hemiptera & Aphididae & 3 & 14 \\
Rose & Spider mite & Trobidiformes & Tetranychidae & 6 & 6 \\
& Aphid & Hemiptera & Aphididae & 5 & 12 \\
Total & & & & $\mathbf{6 5}$ & $\mathbf{1 8 3}$ \\
\hline
\end{tabular}

According the figure 2, December was the month with major number of infested plants $(n=$ 17). During July, August (2018), May and June (2019) no insects were found. This possible occurred because Cerrado regions has two well definited stations: a dry and a rainy periods. Most arthropods in this work was colleted in the rainy period. Dry and rainy periods can influence the pests abundance, and the rainy period is more favorable to many arthropods development, increasing the population (Oliveira and Frizzas, 2008).
The plant species with the highest number of infested individuals was the desert rose, representing $29 \%$ of all collected material. Fifteen A. obesum plants were highly infested by whitefly [Bemisia tabaci (Hemiptera: Aleyrodidae)], containing eggs, nymphs, and adults on the under part of the leaves. McKenzie et al. (2009) included A. obesum as a host plant of B. tabaci in Florida, USA. The main damage of this insect is from their intense sap sucking and it is also an important transmitter of viruses, especially those belonging to the geminivirus group (Haji et al., 2005). In 
addition to the whitefly, scale insect from the Coccidae family (Hemiptera) was found on eight $A$. obesum plants. All desert rose plants that were infested showed symptoms of sooty mold, caused by the fungus Capnodium sp., which can hinder the photosynthesis process of the plant (Chomnunti et al., 2014). Coccids were also found in ixora and all plants also showed symptoms of sooty mold. In the present study, $18.45 \%$ of the samples collected were coccids, which mainly damage plants through their intense suction of elaborated sap, in addition to favoring the growth of the fungus that causes sooty mold.

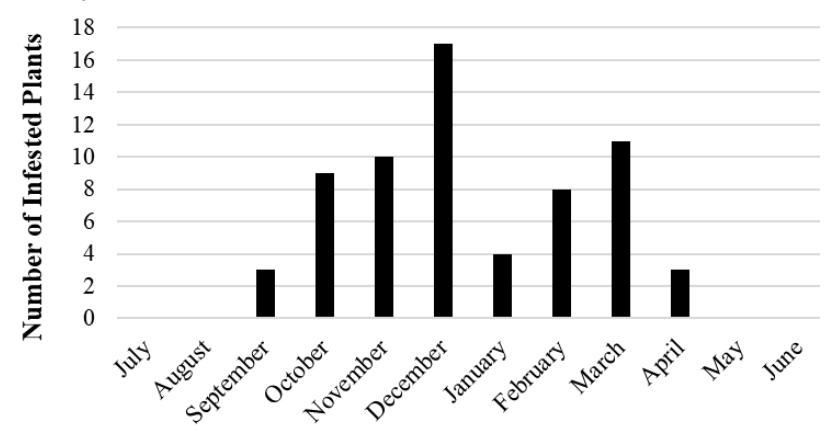

Figure 2 - Number of infested plants by arthropods in supermarkets per month (July 2018 to June 2019).

Scale insects (Hemiptera: Pseudococcidae) were present on $20 \%$ of infested plants, in four different plant species (elephant's foot, centipede tongavine, asparagus fern, and justicia). These insects are popularly known as mealybugs and are common in ornamental species, both herbaceous and shrubs. They feed on the phloem of any part of the plant and can transmit diseases, causing great economic losses in many agronomic crops (Mani e Shivaraju, 2016).

Another very important arthropod observed in this study was the spider mite. It is considered a serious pest of several agricultural crops, especially strawberry, causing damage mainly to the leaves of the plants (Silva et al., 2002). In intense attacks, the plant can be completely covered by web, a fact observed in this work in azalea and rose plants, especially in flowers. If the control is not carried out, the attacked parts can dry out and later fall (Nakano et al., 1992). In addition, the flowers are ugly, displaying a negative appearance, which can lead to the rejection by the consumer. The arruda plants attacked by the mite had intense discoloration of the leaves and a twisted appearance, which can also harm their commercialization.

Finally, aphids of the genus Aphis (Hemiptera: Aphididae) were found associated with eight plants, including roses and peppers. Aphids are very important for agriculture, due to their ability to transmit pathogens, especially viruses (NG e Perry, 2004; Triplehorn e Johnson, 2005; Baldin e Fujihara, 2016). In addition, like all the other sucking insects mentioned above, aphids are able to promote the growth of sooty mold, disrupting photosynthesis. The insects were found mainly in the terminal shoots of the plants, causing deformations in the apical bud.

The high number of infested plants in this study may have occurred by a deficient control in the proccess production, transport and bad storage conditions. Many insects and pathogens can be accidentally disseminated around the world from the native regions (Hurley et al., 2016). Invasive populations can cause many environmental and ecological consequences, including in the evolucionary aspects (Garnas et al., 2016).

Although the insects found are relatively common and have been reported as associated with several ornamental plants, this is the first work that records the occurrence of arthropods in ornamentals sold in commercial establishments. In addition, the results of this study showed that many arthropods can be disseminated to other areas through infested plants offered for sale in supermarkets, and an inspection of this products must be carried out.

\section{CONCLUSIONS}

Sixty-five plants were found infested with arthropods during this study, including sucking insects from the families Coccidae, Pseudococcidae, Aleyrodidae, and Aphididae, in addition to the spider mite (T. urticae). Many of the plants analyzed look bad, which may hinder the sale.

\section{ACKNOWLEDGEMENTS}

We thank to "Núcleo Interdisciplinar de Pesquisa (NIP), Centro Universitário ICESP de Brasília”, for financial support.

\section{REFERENCES}

Baldin ELL, Fujihara RT. Ordem Hemiptera. In: Insetos de Importância Econômica: Guia Ilustrado para Identificação de Famílias. Editora FEPAF, Botucatu, SP, 391p. 2016.

Campos-Farinha AEC. Insetos sugadores pragas das plantas ornamentais. In: Reunião Itinerante de Fitossanidade do Instituto Biológico, 14, Pariquera-Açu, SP. Anais... Pariquera-Açu: Instituto Biológico, p.34-38, 2006. 
Costa EC, D’Ávilla M, Cantarelli EB. Entomologia Florestal. Santa Maria: Editora UFSM, 239p. 2008.

Chomnunti P, Hongsanan S, Hudson BA, Tian Q, Peršoh, D, Dhami MK, Alias AS, Xu, J, Liu X, Stadler M, Hyde KD. The Sooty Moulds. Fungal Diversity, v.66, p.1-36, 2014. http://dx.doi.org/10.1007/s13225-014-0278-5.

Ducroquet J-PHJ. Qualidade sanitária das mudas de frutíferas. Informativo SBF, Cruz das Almas, v.15, n.1, p.10-12, 1996.

Feres RJF, Vieira MR, Daud RD, Pereira Jr EG, Oliveira GF, Dourado CL. Ácaros (Arachnida, Acari) de plantas ornamentais na região noroeste do estado de São Paulo, Brasil: inventário e descrição dos sintomas causados pelos fitófagos. Revista Brasileira de Entomologia, v.53, n.3, p.466474, 2009. https://doi.org/10.1590/S008556262009000300024

Fraga FB, Alencar IDCC, Tavares MT. Disseminação de insetos-praga por meio de embalagens à base de amido extrusado. Neotropical Entomology, v.38, n.4, p.548-549, 2009. http://dx.doi.org/10.1590/S1519 566X2009000400019.

Fujihara RT, Forti LC, Almeida MC, Baldin ELL. Insetos de importância econômica: guia ilustrado para identificação de famílias. Botucatu: FEPAF, 391p. 2016.

Gallo D, Nakano O, Silveira Neto S, Carvalho RPL, Baptista GC, Berti Filho E, Parra JRP, Zucchi RA, Alves SB, Vendramin JD, Marchini LC, Lopes JRS, Omoto C. Entomologia agrícola. Piracicaba: FEALQ, 920p. 2002.

Garnas J, Auger-Rozenberg MA, Roques A, Bertelsmeier C, Wingfield MJ, Saccaggi DL, Roy HE, Slippers B. Complex patterns of global spread in invasive insects: eco-evolutionary and management consequences. Biological Invasions, v.18, p.935-952, 2016. https://doi.org/10.1007/s10530-016-1082-9.

Governo do Distrito Federal. Secretaria de Desenvolvimento Econômico e Turismo do Distrito Federal - SDET. Fóruns Estratégicos do Distrito Federal. Brasília: SDE, 79p. 2007.

Haji FNP, Mattos MAA, Alencar JA, Barbosa FR, Paranhos BJ. Manejo da Mosca-Branca na Cultura do Tomate. Embrapa-Semi-Árido, Petrolina, PE. Circular Técnica da Embrapa Semi Árido 81, 16p, 2005.

Hickel ER, Schuck E, Ducroquet J-PHJ. Expurgo de mudas de frutíferas de clima temperado: método alternativo para evitar disseminação de pragas. Agropecuária Catarinense, v.10, n.2, p.8-11, 1997.

Hurley BP, Garnas J, Wingfield MJ, Branco M, Richardson DM, Slippers B. Increasing numbers and intercontinental spread of invasive insects on eucalypts. Biological Invasions, v.18, p.921-933, 2016.

https://doi.org/10.1007/s10530-016-1081-x.

Imenes SDL, Ide S. Principais grupos de insetos pragas em plantas de interesse econômico. O Biológico, São Paulo, v.64, n.2, p.235-238, 2002.

Mani M, Shivaraju C. Mealybugs and their Management in Agricultural and Horticultural Crops. Spring, New Dheli, India, 982p. 2016.

McKenzie CL, Hodges G, Osborne LS, Byrne FJ, Shatters Jr RG. Distribution of Bemisia tabaci (Hemiptera:
Aleyrodidae) Biotypes in Florida-Investigating the Q Invasion. Journal of Economic Entomology, v.102, n.2, p.670676, 2009. http://dx.doi.org/10.1603/029.102.0227.

Nakano O, Parra JRP, Marchini LC. Pragas das hortaliças e ornamentais. In: FEALQ. Curso de Entomologia aplicada a agricultura. Piracicaba: FEALQ, p.441-476, 1992.

Neves MF, Pinto MJA. Mapeamento e quantificação da cadeia de flores e plantas ornamentais do Brasil. São Paulo: OCESP, 122p. 2015.

Ng JCK, Perry KL. Transmission of plant viruses by aphid vectors. Molecular Plant Pathology, v.5, p.505-511, 2004. https://doi.org/10.1111/j.1364-3703.2004.00240.x

Oliveira CM, Frizzas MR. Insetos de Cerrado: distribuição estacional e abundância. Boletim de Pesquisa e Desenvolvimento 216, Embrapa Cerrados, 26p. 2008.

Picanço MC. Manejo Integrado de Pragas. Departamento de Biologia Animal. Universidade Federal de Viçosa, Viçosa, MG. 2010. http://www.ica.ufmg.br/insetario/images/apostilas/apostila_entomologia_2010.pdf. Access on: 02/12/2020.

Rosa FSD, Lunkes RJ. A Logística das Flores: Uma Contribuição ao Estudo sobre a Cadeia. III Simpósio de Excelência em Gestão e Tecnologia, 12p. 2006.

Santos RMV, Noronha ACS, Oliveira AR, Bittencourt MAL. Ácaros (Arachnida: Acari) associados a plantas ornamentais tropicais na região litoral sul da Bahia. Arquivo Instituto Biológico, v.77, n.1, p.43-48, 2010.

Silva LFA. Comercialização de flores e plantas ornamentais em supermercados do Distrito Federal e entorno. Ano de obtenção: 2016. 33p. Monografia (Curso de Agronomia) Faculdade de Agronomia e Medicina Veterinária, Universidade de Brasília, Brasília.

Silva PM, Sato ME, Souza Filho MF, Raga A. Monitoramento da resistência de Tetranychus urticae (Koch, 1936) (Acari: Tetranychidae) a propargite no estado de São Paulo. In: Reunião Anual do Instituto Biológico, 15, São Paulo. v.69, p.1-306, 2002.

Sulzbach M, Ott R, Schafer G, Ott AP. Abundância e sazonalidade do ácaro-rajado em cultivares de gérbera. Ciência Rural, v.45, n.4, p.1-7, 2015. http://dx.doi.org/10.1590/0103-8478cr20131494

Tamai MA, Lopes RB, Alves SB. Manejo de Pragas na Floricultura. 2000. <http://www.biologico.sp.gov.br/rifib/IIIRifib/66-70.pdf>. Access on: 02/23/2020.

Triplehorn CA, Johnson NF. Borror and DeLong's introduction to the study of insects. 7. ed. Belmont: Thomson Brooks/Cole, 864p. 2005. 